\title{
Investigating the Mixed Effect of Green Marketing on the Decision of Green Buying Consumers (Case Study: Consumers of Mihan Company's Dairy Products in Arak)
}

\author{
Sara Narimanfar ${ }^{1 *}$ (), Kiyana Hatam Nezhad ${ }^{1}$ (i)
}

${ }^{1}$ Islamic Azad University, IRAN

*Corresponding Author: sara.narimanfar@gmail.com

Citation: Narimanfar, S. and Hatam Nezhad, K. (2022). Investigating the Mixed Effect of Green Marketing on the Decision of Green Buying Consumers (Case Study: Consumers of Mihan Company's Dairy Products in Arak). European Journal of Sustainable Development Research, 6(1), em0178. https://doi.org/10.21601/ejosdr/11554

\section{ARTICLE INFO}

Received: 19 Sep. 2021

Accepted: 2 Jan. 2022

\begin{abstract}
Green marketing or the environment includes all activities that produce and facilitate any currency exchanged for the meeting of human needs and wants designed to satisfy these needs and wants with the least harmful impact on the natural environment. The present study aims to examine consumers' attitudes towards the mix of green marketing and its effect on decision-making. Based on this, a sample consisting of 385 consumers of dairy products of the mentioned company was selected and examined in Arak city by the stratified random method according to the volume of each class. The conceptual model of the research was designed based on the theoretical studies of green marketing and consumer buying, and based on it, a questionnaire was created, and the data were collected. Based on the results, green products did not significantly affect consumer green purchase. On the other hand, the green marketing mix reflects $69 \%$ of consumer change in green purchases. Finally, each of the dimensions of advertising (0.49), distribution (0.25), and the price of the market mix Green $(0.28)$ has a positive and significant effect on the green purchase of the consumer. In contrast, the green product has a negative and insignificant impact on the green purchase of consumers.
\end{abstract}

Keywords: green marketing, green price, green promotion, dairy products, decision-making, green purchase decision

\section{INTRODUCTION}

Environmental pollution caused by human production and consumption is one of the issues that have been repeatedly recognized as a threat to human beings by organizations active in this field. Meanwhile, some industries have taken steps to reduce the final effects on the environment by taking action. These include green marketing or environmental friendliness; Environmental and natural development of marketing activities, using the role of ecological/social responsibility of companies for sustainable development (Cao, 2011). In these measures, companies must do their part in producing, distributing, advertising, and pricing products. While minimizing environmental damage also leads consumers to environmentally friendly behavior (Nakhaei and Kheiri, 2012). These actions and their consequences have been studied in this study.

\section{Statement of the Problem}

In the new century, humanity's main challenge is finding a fair and sustainable way to produce, consume, and live.
Meanwhile, consumer concerns over environmental responsiveness, which have been aligned with environmental regulations, have put pressure on a growing number of companies to design and create environmentally friendly programs (Min and Galle, 2001) Therefore, companies must significantly reduce their negative environmental impacts on production, distribution, supply of raw materials, and energy consumption. Otherwise, customers will be pushed back by strict rules and demands (Grant, 2008). Therefore, the best strategy for marketers is to provide detailed information concerning the environmental credentials of their products to customers (Hartmann and Apaolaza, 2006). In this regard, the company should attract customers' attention by informing them of their measures to green their activities. McDonald's, for example, has announced to consumers that it has taken steps to reduce losses during marketing activities by promoting the consequences of failures (Grovo et al., 1996).

On the other hand, as people's environmental problems are increasing daily, their ecological awareness needs to be improved (Johri and Sahasakmontri, 1998). This is because customers need the information to make an informed 
purchase, and a lack of knowledge can prevent them from using the green criteria and features when deciding to buy them (Prakash, 2002). This information is a crucial aspect of green marketing. Companies should not express the product's environmental benefits as long as the validity of such claims is proven because it may result in a negative outcome (Prakash, 2002).

Being part of this world, human beings should be responsible to protect the earth from any exploitation of the environment in a rampant manner (Julia et al., 2016). Environmental consciousness among consumers globally is gaining positive attention; as a result, promoting green consumption to ensure healthy living and protection of the environment is gaining acceptance (Dangelico and Vocalelli, 2017; Yu et al., 2018). As part of the Sustainable Development Goals (SDGs), nations seek to protect the Earth from rapid degradation to ensure prosperous living standards by 2030 (Briceño and Santos, 2019; United Nations, 2015; Zinkernagel et al., 2018). Hence, Goal 12 of the 2030 global agenda seeks to attain sustainable consumption and production that protect the environment because a sustainable environment remains fundamental to human survival and wellbeing on Earth. Therefore, there is a need to have a paradigm shift from conventional purchase behavior to green purchase behavior to reduce the negative impact on the environment (Quoquab and Mohammad, 2016; Quoquab et al., 2019).

\section{Research Objectives}

According to the topics discussed above, the objectives of the present study are as follows:

1. Examining the attitude of consumers towards green marketing mixes and its effect on the consumer's decision to green purchase.

2. 2-Prioritize each of the mixtures according to the importance of their effect on the consumer's decision to green purchase.

\section{Research Hypotheses}

Our research hypothesis is as follows:

H1: Green marketing mix affects on the consumer's decision to green purchase.

Our sub-hypotheses are as follows:

1. H1.1: Green product has a positive and significant effect on the consumer's decision to green purchase.

2. H1.2: Green distribution has a positive and significant effect on the consumer's decision to green purchase.

3. H1.3: Green price has a positive and significant effect on the consumer's decision to green purchase

4. H1.4: Green promotion has a positive and significant effect on the consumer's decision to green purchase.

\section{THE CONCEPTUAL MODEL OF RESEARCH}

Lee (2008) examined green marketing and consumer behavior. Inside the country, people such as Ramezanian et al. (2010) examined the effect of mixed marketing on the decision-making process of consumer consumers of energysaving lamps, each of which has some precious results also has

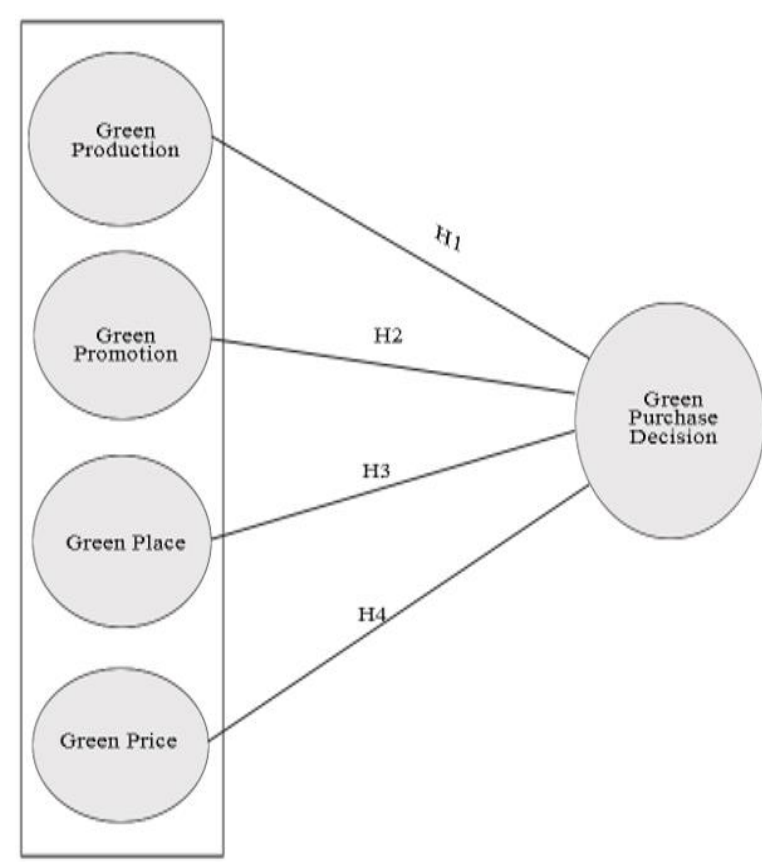

Figure 1. Conceptual research model

limitations. Another necessity is that most of the studies in this field are related to Western countries, which are focused on consumers in those countries, while consumers in other parts of the world can have different attitudes and opinions about marketing activities. Therefore, the results of these studies may not apply to Iranian consumers who have different cultures, beliefs, and attitudes toward Western consumers. Based on the above, in this study, in the framework of the conceptual model listed in Figure 1 and focusing on domestic consumers, their attitudes towards the green marketing mix of Pegah Arak Dairy Dairy Company are evaluated effect. Their green purchase should be considered. Mihan was chosen to be studied because almost all variables, including green product, green price, green advertising, green distribution, and green shopping, apply correctly in this company and we want to examine the relationships between consumers' attitudes toward the greenness of the four green marketing mixes and their impact on consumer green purchases. Changes in consumer green purchases and this shows that other companies active in the field of dairy products can also significantly affect consumer purchases and benefit from its marketing activities by greening their marketing activities.

To make the concepts used in the research model operational, each of these concepts has been discussed in detail. After reviewing the views presented about each of them, efforts have been made to measure appropriate criteria and indicators for measuring each. The concept to be extracted.

\section{Green Product}

The term green refers to a product when its environmental and social performance has been significantly improved in production, use, and disposal compared to other competing products (Peattie and Crane, 1995, cited in Dangelico and Pontrandolfo, 2009). The term green crop is a product that does not harm the environment and also contains elements that are not potentially harmful to the environment (Borin et al., 2011). Another definition of the green crop is a product 
Table 1. Green product criteria

\begin{tabular}{ccc}
$\begin{array}{c}\text { Green } \\
\text { marketing mix }\end{array}$ & Measurement criteria & $\begin{array}{c}\text { Question number related } \\
\text { to questionnaire }\end{array}$ \\
\hline & $\begin{array}{c}\text { Contains elements that are not harmful to the environment (Borin et al., 2011; Gurãu and } \\
\text { Ranchod, 2004; Lee, 2008; Mahenc, 2008; Polonsky and Rosenberger III, 2001) }\end{array}$ & - \\
\cline { 2 - 3 } Green product & $\begin{array}{c}\text { Effective in terms of energy consumption (Dangelico and Pontrandolfo, 2009; Lee, 2008; } \\
\text { Polonsky and Rosenberger III, 2001) }\end{array}$ & - \\
\cline { 2 - 3 } & $\begin{array}{c}\text { Made of materials that provide recyclability for the product (Chen and Chai, 2010; Dangelico and } \\
\text { Pontrandolfo, 2009; Lee, 2008) }\end{array}$ & 2 \& 3 \\
\cline { 2 - 3 } & The production process of that product is bio-friendly (Gurãu and Ranchod, 2004; Peattie and \\
& Crane, 2005) & - \\
\cline { 2 - 3 }
\end{tabular}

Table 2. Green advertising criteria

\begin{tabular}{|c|c|c|}
\hline $\begin{array}{c}\text { Green } \\
\text { marketing mix }\end{array}$ & Measurement criteria & $\begin{array}{c}\text { Question number related } \\
\text { to questionnaire }\end{array}$ \\
\hline \multirow{4}{*}{ Green ad } & $\begin{array}{l}\text { Promote a green lifestyle (Cox, 2008) } \\
\end{array}$ & $14,15, \& 16$ \\
\hline & Express the environmental responsibility of the company (Cox, 2008) & $8,9,10, \& 11$ \\
\hline & $\begin{array}{l}\text { Explain the environmental characteristics of the product } \\
\text { (Gurãu and Ranchod, 2004; Polonsky and Rosenberger III, 2001) }\end{array}$ & $12 \& 13$ \\
\hline & $\begin{array}{l}\text { Increase consumer awareness of environmental issues } \\
\text { (Polonsky and Rosenberger III, 2001) }\end{array}$ & $17,18,19, \& 20$ \\
\hline
\end{tabular}

with such criteria: Designed to be usable, reassembled, and reused, as well as materials that can be recycled. It is more efficient in terms of energy consumption and creates less environmental pollution than other products (Dangelico and Pontrandolfo, 2009). In general, it can be defined as a product that causes less environmental damage (Mahenc, 2008). In their study, Schlegelmilch et al. (1996) divided green goods into several categories: general green goods, recyclable paper products, non-tested animal products, environmentally friendly products, ozone-compatible gases, etc. so on products that are energy efficient. According to the above discussion, a green product can be examined according to the criteria listed in Table 1.

\section{Green Advertising}

Banerjee et al. (1995) has defined green advertising as advertising that has at least one of these criteria:

1. Explicitly or implicitly express the relationship between a product or service and the environment.

2. Promote a kind of green lifestyle.

3. Express the company's environmental responsibility (Cox, 2008).

According to Polonsky and Rosenberger III (2001), an environmentally friendly advertisement includes information or claims about how an advertised or promotional product can improve the environment and reduce destruction. Participate in it (Chan et al., 2006). Green advertising has promoted as any advertising that includes environmentally friendly messages and environmental sustainability that defines the needs and wants of shareholders with ecological concerns (Leonidou et al., 2010). Polonsky and Rosenberger III (2001) also point to green promotions as promoting the environmental characteristics of products, arguing that such advertisements should bring ecological information to the attention of customers who are associated with the company. In this regard, a group of researchers such as Haytko and Matulich (2008) examined the effect of green advertising on consumer- friendly environmental behavior and concluded that women are more responsible for the environment and have a more positive attitude towards advertising and green goods. A group of studies also found that sometimes had different results, for example, while Schuhwerk and Lefkoff-Hagius (1995) found that only consumers with less environmental involvement were positively affected by green advertising. D'Souza and Taghian (2005) have shown the opposite in their studies. Therefore, green marketers should be allowed to use green advertising as a tool to reach potential customers (Abbasi et al., 2012). In this way, the consumer is aware of how the product helps to protect the environment and is encouraged to buy from the product. According to the topics mentioned earlier, green promotions should have the characteristics listed in Table 2.

\section{Green Price}

Green price is defined as setting prices for green goods in a way that balances consumer sensitivity to cost and the willingness to pay more for environmentally friendly goods (Grove et al., 1996). Johri and Sahasakmontri (1998) also stated that the criteria that consumers consider when buying are good value for money. Various studies show the importance of price in buying a customer and his satisfaction. Among the studies in this field are Herrmann et al. (2007), who believe that price is an essential factor in customer buying; Therefore, it significantly affects customer satisfaction. Consumer satisfaction is also directly affected by price perception and indirectly by a fair price. In another study, Lee et al. (2011) examined how consumer perception affect its purchasing decision's cost fairness and named it a suitable predictor for consumer purchasing decision. Therefore, the requirements of a green price listed in Table 3 .

\section{Green Distribution}

In this context, the studies conducted mainly on the topic of the green supply chain are focused on a detailed discussion and beyond the green distribution that is considered in this 
Table 3. Green price criteria

\begin{tabular}{ccc}
\hline $\begin{array}{c}\text { Green } \\
\text { marketing mix }\end{array}$ & Measurement criteria & $\begin{array}{c}\text { Question number related } \\
\text { to questionnaire }\end{array}$ \\
\hline \multirow{2}{*}{ Green price } & Fair price (Herrmann et al., 2007; Lee et al., 2011) & 6 \\
\cline { 2 - 3 } & Provide good value for money (Johri and Sahasakmontri, 1998) & 7 \\
\hline
\end{tabular}

Table 4. Green distribution criteria

\begin{tabular}{|c|c|c|}
\hline $\begin{array}{c}\text { Green } \\
\text { marketing mix } \\
\end{array}$ & Measurement criteria & $\begin{array}{c}\text { Question number related } \\
\text { to questionnaire }\end{array}$ \\
\hline \multirow{5}{*}{$\begin{array}{c}\text { Green } \\
\text { distribution }\end{array}$} & Optimal use of available space & - \\
\hline & The use of a fleet that is new and environmentally friendly & $4 \& 5$ \\
\hline & Use green hash fuels such as those with low sulfur content and also use alternative fuels & - \\
\hline & Use of rail and shipping lines for bulky cargo & - \\
\hline & Encourage people to drive cheaply to reduce fuel waste (Shah, 2019) & - \\
\hline
\end{tabular}

Table 5. Green shopping criteria

\begin{tabular}{|c|c|c|}
\hline $\begin{array}{c}\text { Green } \\
\text { marketing mix }\end{array}$ & Measurement criteria & $\begin{array}{l}\text { Question number related } \\
\text { to questionnaire }\end{array}$ \\
\hline \multirow{6}{*}{ Green shopping } & $\begin{array}{l}\text { Be aware of environmental issues (Gan et al., 2008; Laroche et al., 2001; Nelson et al., 2009; } \\
\text { Schlegelmilch et al., 1996) }\end{array}$ & 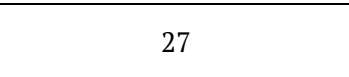 \\
\hline & $\begin{array}{l}\text { When buying, pay attention to the elements that make up the product and the effect it has on } \\
\text { the environment (D'Souza et al., 2006; Johri and Sahasakmontri, 1998) }\end{array}$ & - \\
\hline & $\begin{array}{l}\text { Consider the quality of the green product (Gan et al., 2008; Hosseinzadeh, 2010; Schlegelmilch } \\
\text { et al., 1996) }\end{array}$ & 23 \\
\hline & Consider the type of product packaging and its recyclability (D’Souza et al., 2006) & $21 \& 22$ \\
\hline & $\begin{array}{l}\text { Pay attention to the price of the product (Gan et al., 2008; Schlegelmilch et al., 1996; Shah, } \\
\text { 2019) }\end{array}$ & 24 \\
\hline & And add environmental aspects to other criteria of your purchase (Shah, 2019) & $25 \& 26$ \\
\hline
\end{tabular}

study. Distribution increases the environmental impact of products and is therefore constantly being considered to meet ecological requirements. The natural environment as a result of local and global environmental problems in recent years, it has become a challenging issue for businesses. It is believed that business activities such as retrieval, production, and transportation should be responsible for these problems (Beamon, 1999; cited in Eltayeb et al., 2011). According to Laroche et al. (2001), most customers claim that they will not buy companies accused of environmental pollution. Companies that do not comply with environmental laws and seek to exploit ecological issues to increase their sales will be subject to customer sanctions. In this regard, among the measures that companies can take to green their distribution system listed in Table 4.

\section{The Decision to Buy Green}

Green shopping means adding environmental aspects to criteria such as price and function when deciding to buy, with the ultimate goal of reducing the environmental impact of finding resources and increasing resource productivity. Schlegelmilch et al. (1996) examined the relationship between green shopping decisions and awareness of ecological issues and concluded that customer awareness of the environmental problems affects the decision to buy green. However, other modifiers should also be affected. The findings also suggest that trends and perceptions are the best predictors of green shopping decisions. Studies conducted by Johri and Sahasakmontri (1998) on cosmetics purchase in Thai consumers also concluded that Thai consumers in buying green cosmetics have good value for money and product performance and base immunity on the skin. Two environmental characteristics that are important to them are the constituent elements of the product and its lack of testing on animals. From D'Souza et al. (2006), green consumers are more inclined to examine the goods in terms of packaging type and its constituent elements than other factors. In another study, Gan et al. (2008) looked at customer behavior toward green goods in New Zealand and concluded that consumers who are aware of environmental issues are more likely to buy green products. Also, the traditional aspects of the development, such as price, quality, and brand name, are among the essential factors that people consider when deciding to buy. In addition, people who are married or about to get married are more likely to buy green goods because they are more concerned about their health and the health of their families and future generations. Nelson et al. (2009) also show that consumers who are aware of the environment will be encouraged to engage in environmentally friendly shopping behavior. Hosseinzadeh (2010) also claimed in his study that given the positive attitudes towards the environment among Tehran consumers and its positive correlation with green shopping, if they are assured of the quality of green goods, they will buy these goods. However, a green purchase is made when the buyer has the characteristics listed in Table 5 .

\section{RESEARCH METHODS}

This research can be considered as a descriptive research based on how to obtain the desired data, and because the data is done by sampling of the community to study the distribution of the characteristics of the statistical population, this research is a survey. 
Table 6. Information on the population of the six regions of Arak

\begin{tabular}{ccccc}
\hline Row & Regional municipality & Population of each region & Relative frequency (\%) & Share of sample \\
\hline 1 & Region 1 & 110,884 & $18 / 73$ & 62 \\
\hline 2 & Region 2 & 111,225 & $18 / 80$ & 75 \\
\hline 3 & Region 3 & 111,069 & $18 / 77$ & 68 \\
\hline 4 & Region 4 & 110,933 & $18 / 74$ & 65 \\
\hline 5 & Region 5 & 111,098 & $18 / 78$ & 41 \\
\hline 6 & Region 6 & 36,517 & $6 / 18$ & 38 \\
\hline
\end{tabular}

Table 7. Statistical description of demographic characteristics

\begin{tabular}{|c|c|c|}
\hline Demographic variable name & Levels & Frequency \\
\hline \multirow{2}{*}{ Gender } & Male & 53 \\
\hline & Female & 47 \\
\hline \multirow{5}{*}{ Education } & High school & $2 / 8$ \\
\hline & Diploma & $3 / 20$ \\
\hline & Associate degree & $4 / 26$ \\
\hline & Bachelor & $5 / 32$ \\
\hline & Master's degree or higher & $7 / 12$ \\
\hline \multirow{2}{*}{ Maritul status } & Single & $1 / 39$ \\
\hline & Married & $9 / 60$ \\
\hline \multirow{6}{*}{ Age } & Less than 20 & $4 / 5$ \\
\hline & $20-30$ & $5 / 38$ \\
\hline & $31-40$ & $6 / 39$ \\
\hline & $41-50$ & $9 / 12$ \\
\hline & $51-60$ & $2 / 4$ \\
\hline & 60 and above & $1 / 1$ \\
\hline
\end{tabular}

Society and statistical sample of research the statistical population of the present study is all consumers of dairy products of the Mihan Company in Arak city. Because the number of members of the statistical population is unlimited, the sample size calculation method was used when the population was unlimited. The number of sample members was calculated using the following formula:

$$
n=\frac{z^{2} p q}{d^{2}}=384 \text {. }
$$

Regarding the sampling method, the stratified random sampling method was used in proportion to the volume of each stratum, so that Arak city was divided into six municipal districts as it includes 6 regions and then random sampling members were selected from each region according to the population of that sample. A questionnaire was distributed among them.

Table 6 summarizes the information on the six regions of Arak and the number of selected samples from each region. The population demographics of the statistical sample are also shown in Table 7.

\section{Data Collection Tools}

The questionnaire designed for the present study consists of two sections and 27 questions, which is part of a comprehensive questionnaire on green marketing and is designed using a seven-point Likert scale (from very low to very high). The first part of the questionnaire includes the respondents' demographic information. The second part is related to the attitude of consumers towards the green marketing mix and its effect on their green purchase. Tables 1-5 summarize the research variables and their measurement criteria. It should be noted that since the company under study in this research (Mihan Company) is active in the field of dairy production, in examining the green product from the mix of green marketing and green purchase, some indicators so they did not apply to dairy products, they were not used in designing questions. Concerning green distribution, because some indicators were not measured in terms of consumer information, they were not used in creating queries.

\section{Validity and validity of the questionnaire}

Among the methods of determining the validity of the questionnaire is the method of validating the content. Thus, if the tool or method of data collection includes all the dimensions and contents of the variable or the desired concept, it has the validity of the content. Otherwise, it lacks the validity of the content (Mirzaei, 2010). For this purpose, in the present study, an attempt was made to study and extract all the dimensions of the research variables by studying the theoretical foundations. Then the relevant questionnaire should be designed based on them. Cronbach's alpha was also used to investigate the reliability of the questionnaire, and all alpha coefficients indicate the desired level of reliability of the questionnaire. Table 8 summarizes the alpha coefficients of the corresponding variable questions.

\section{Analyzing the results and findings of the research}

In order to examine the data, first, the population characteristics of the sample members were examined using IBM SPSS Statistics 20 software, and then the model was presented, and the hypotheses were tested using SPSS Amos 20 software, the results of which are as follows. The analysis 
Table 8. Cronbach's alpha coefficient for the research questionnaire

\begin{tabular}{ccc}
\hline Variables & Number of questions & Cronbach's alpha coefficients (\%) \\
\hline Green product & 3 & 82 \\
\hline Green price & 2 & 71 \\
\hline Green ad & 13 & 94 \\
\hline Green distribution & 2 & 73 \\
\hline Green shopping & 7 & \\
\hline Total & 27 & 94 \\
\hline
\end{tabular}

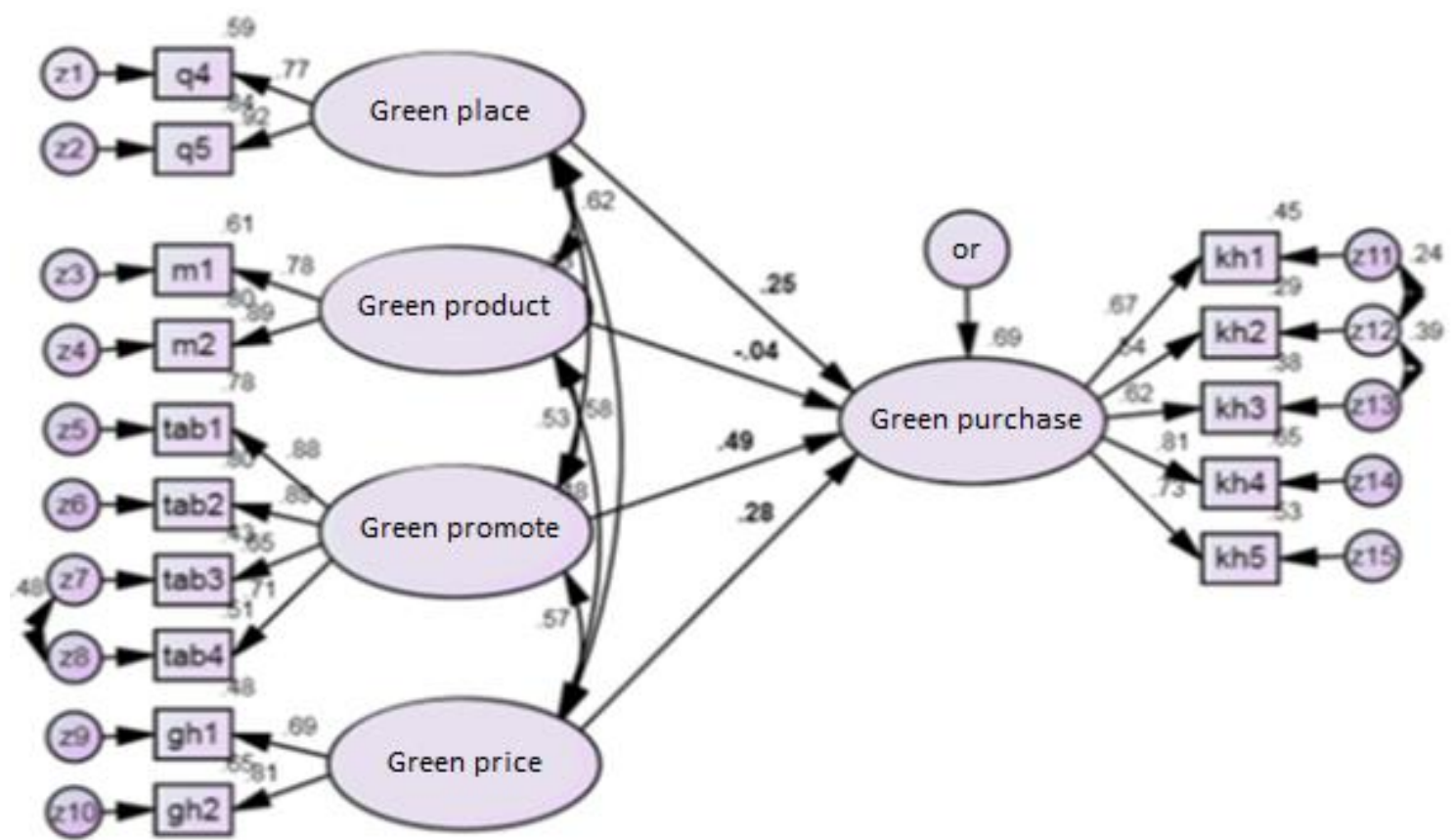

Figure 2. Structural equation model extracted with standard coefficients

Table 9. Model fit indicators

\begin{tabular}{|c|c|c|c|c|c|c|}
\hline IFI & AGFI & NFI & CFI & GFI & RMSEA & Index \\
\hline $0 / 93$ & $0 / 86$ & $0 / 91$ & $0 / 93$ & $0 / 91$ & $0 / 09$ & Amount \\
\hline $0 / 9<X$ & $\begin{array}{l}\text { The closer it is to } \\
\text { the number one } \\
\text { is better }\end{array}$ & $0 / 9<\mathrm{X}$ & $0 / 9<X$ & $\begin{array}{l}\text { The closer it is to the } \\
\text { number one is better }\end{array}$ & $\begin{array}{c}\text { Good } \\
\mathrm{X}<0 / 5 \\
\text { Medium } 0 / 08>\mathrm{X}>0 / 05 \\
\text { Weak } \\
\mathrm{X}>0 / 08\end{array}$ & Standard value \\
\hline
\end{tabular}

Chi-square=9/294; $\mathrm{df}=77 ;$ sig $=0.00$

Table 10. Standard coefficients and significant model numbers

\begin{tabular}{|c|c|c|c|c|}
\hline Row & Assumptions & $\begin{array}{c}\text { Standard } \\
\text { coefficient }\end{array}$ & $\begin{array}{c}\text { Significant } \\
\text { number }\end{array}$ & Conclusion \\
\hline 1 & $\begin{array}{l}\text { Positive and significant relationship between attitude towards green product and customer's } \\
\text { decision to buy green (Hypothesis 1) }\end{array}$ & $-0 / 04$ & $-0 / 63$ & Reject \\
\hline 2 & $\begin{array}{l}\text { Positive and significant relationship between green advertising attitude and customer } \\
\text { decision to buy green (Hypothesis } 2 \text { ) }\end{array}$ & $0 / 49$ & $6 / 95$ & Confirmation \\
\hline 3 & $\begin{array}{l}\text { Positive and significant relationship between the attitude towards green distribution and the } \\
\text { customer's decision to buy green (Hypothesis 3) }\end{array}$ & $0 / 25$ & $3 / 55$ & Confirmation \\
\hline 4 & $\begin{array}{l}\text { Positive and significant relationship between attitude towards green price and customer's } \\
\text { decision to buy green (Hypothesis } 4 \text { ) }\end{array}$ & $0 / 28$ & $3 / 64$ & Confirmation \\
\hline
\end{tabular}

results show that the best-fitted model for the data studied is the structural equation model shown in Figure 2.

In the structural equation model, to examine the model's fit, a set of indicators must be considered, although, in practice, the use of four or five indicators is sufficient. Table 9 shows some of these indicators, which show that the model of this study is in a good position in terms of these indicators, which indicates the adequacy of the data. Table 10 also summarizes the results of the analysis.

As the results show, the effect of green product on consumer green purchase is (-0.04) and given that its significance number $(-0.63)$ is greater than $(-1.96)$, the first 
hypothesis of the research is rejected. Also, the effect of green advertising on green purchase (0.49) shows the direct and average effect of green advertising on green consumer consumption, in addition, because its significant number (6.95) is greater than (1.96), the second hypothesis of the research is confirmed. The effect of green distribution on consumer green purchase is also $(0.25)$, which indicates the relatively weak effect of the independent variable on the dependent variable. In addition, its significance number (3.55) is greater than (1.96), the third research hypothesis is confirmed. On the other hand, the effect of green price on consumer green purchase $(0.28)$ indicates the average effect of the independent variable on the dependent variable. Also, the significance number (3.64) is greater than (1.96), the fourth hypothesis is also confirmed.

Considering that one of the other goals of this study is to investigate the importance of the effect of each of the mixtures on consumer green purchases in Mihan Company, the results show that the highest impact is related to the dimensions of advertising, price, and distribution of it is a mixture of green marketing. Based on the obtained results, green products did not significantly affect consumer green purchase, it has not been included in the above prioritization. On the other hand, as shown in Figure 2, the green marketing mix reflects $69 \%$ of consumer change in green purchases, indicating that other dairy companies can also green by expanding their activities. Marketing itself has a significant impact on consumer purchases and benefits. The results showed that consumers' attitudes toward green advertising significantly impact its purchase among green market mixes. Also since attention to the environment can be checked. Obviously, this leads to competitive advantage and ultimately the profitability of companies. Finally, it was suggested that the price and distribution of green have a more significant impact on consumer purchases after green advertising.

\section{CONCLUSIONS}

In this study, all existing relationships between green marketing mixes and consumer green shopping were examined. As the results showed, the first hypothesis of the research based on a positive and significant relationship between attitude towards the green product and consumer green purchase was not confirmed, which of course occurred in the dairy industry and our company (Mihan). Also, the results showed that consumers' attitude towards green advertising among all the mixed dimensions of green marketing has a greater impact on their purchase and green prices and distribution have a greater impact on consumer purchases.

\section{Limitation}

The results of study may be different in other industries and companies. Therefore, other researchers are advised to study their studies in other industries and include more companies in their studies.

\section{Suggestions}

Other companies are advised to pay special attention to the importance and necessity of environmental issues in their advertisements and inform consumers of the measures and activities they have taken to protect the environment and reduce its negative effects on it.

Fair pricing in such a way that consumer price sensitivity is taken into account and also the use of modern and environmentally friendly transport fleet in the distribution of products can be effective in buying green consumers and thus increasing the sales of companies.

Finally, given that the proposed model has good explanatory power for consumers to decide to buy green, other researchers can examine and add additional variables such as green loyalty, green satisfaction, and advertising by the customer, a more comprehensive model. To explain and test the factors affecting the decision to buy green and its benefits.

Author contributions: All co-authors have involved in all stages of this study while preparing the final version. They all agree with the results and conclusions.

Funding: No external funding is received for this article.

Declaration of interest: The authors declare that they have no competing interests.

Ethics approval and consent to participate: Not applicable.

Availability of data and materials: All data generated or analyzed during this study are available for sharing when appropriate request is directed to corresponding author.

\section{REFERENCES}

Abbasi, J., Enayati, G. H. and Rahbari, M. (2012). Investigating factors affecting the green purchasing behavior of Iranian students (Case study: Students of Islamic Azad University of Qazvin). Management Quarterly, 27(9), 36.

Banerjee, S. B., Gulas, C. S. and Iyer, E. (1995). Shades of green: a multidimensional analysis of environmental advertising. Journal of Advertising, 24(2), 21-31. https://doi.org/10.1080/00913367.1995.10673473

Beamon, B. M. (1999). Designing green supply chain. Logistics Information Management, 12(4), 332-342. https://doi.org/ 10.1108/09576059910284159

Borin, N., Cerf, D. C. and Krishnan, R. (2011). Consumer effects of environmental impact in product labeling. Journal of Consumer Marketing, 28(1), 76- 86. https://doi.org/10.1108/ 07363761111101976

Briceño, C. E. B. and Santos, F. C. A. (2019). Knowledge management, the missing piece in the 2030 agenda and SDGs puzzle. International Journal of Sustainability in Higher Education, 20(16), 901-916. https://doi.org/10.1108/ IJSHE-01-2019-0019

Cao, X. (2011). Does it pay to be green? An integrated view of environmental marketing with evidence from the forest products industry in China. UMI Dissertation Publishing.

Chan, R., Leung, T. K. P. and Wong, Y. H. (2006). The effectiveness of environmental claims for services advertising. Journal of Services Marketing, 20(4), 233-250. https://doi.org/10.1108/08876040610674580 
Chen, T. B. and Chai, L. T. (2010). Attitude towards the environment and green products: Consumers' perspective. Management Science and Engineering, 4(2), 27-39.

Cox, M. J. (2008). Sustainable communication: A study of green advertising and audience reception within the growing arena of corporate scial responsibility. Case study: British Petroleum. Earth \& E-nvironment, 3, 32-51.

D’Souza, C. and Taghian, M. (2005). Green advertising effects on attitude and choice of advertising themes. Asia Pacific Journal of Marketing and Logistics, 17(3), 51-66. https://doi.org/10.1108/13555850510672386

D’Souza, C., Taghian, M., Lamb, P. and Peretiatkos, R. (2006). Green products and corporate strategy: an empirical investigation. Society and Business Review, 1(2), 144-157. https://doi.org/10.1108/17465680610669825

Dangelico, R. M. and Vocalelli, D. (2017), “Green marketing”: An analysis of definitions, strategy steps, and tools through a systematic review of the literature. Journal of Cleaner Production, 165, 1263-1279. https://doi.org/10.1016/ j.jclepro.2017.07.184

Dangelico, R.M. and Pontrandolfo, P. (2009). From green product definitions and classifications to the green option matrix. Journal of Cleaner Production, 18(16-17), 16081628. https://doi.org/10.1016/j.jclepro.2010.07.007

Eltayeb, T., Zailani, S. and Ramayah, T. (2011). Green supply chain initiatives among certified companies in Malaysia andenvironmental sustainability: Investigating the outcomes. Resources Conservation and Recycling, 55(5), 495-506. https://doi.org/10.1016/j.resconrec.2010.09.003

Gan, C., Wee, H. Y., Ozanne, L. and Kao, T.-H. (2008). Consumers' purchasing behavior towards green products in New Zealand. Journal of Innovative Marketing, 4(1), 93102.

Grant, J. (2008). Green marketing. Strategic Direction, 24, 2527. https://doi.org/10.1108/02580540810868041

Grove, S. J., Fisk, R. P., Pickett, G. M. and Kangun, N. (1996). Going green in the service sector: Social responsibility issues, implications and implementation. European Journal of Marketing, 30(5), 56-66. https://doi.org/10.1108/ 03090569610118777

Gurãu, C. and Ranchod, A. (2005). International green marketing: A comparative study of British and Romanian firms. International Marketing Review, 22 (5), 547-561. https://doi.org/10.1108/02651330510624381

Hartmann, P. and Apaolaza, V. (2006). View point: Green value added. Marketing Intelligence \& Planning, 24(7), 673-680. https://doi.org/10.1108/02634500610711842

Haytko, D. L. and Matulich, E. (2008). Green advertising and environmentally responsible consumer behaviors: Linkages examined. Journal of Management and Marketing Research, 1.

Herrmann, A., Xia, L., Monroe, K. B. and Huber, F. (2007). The influence of price fairness on customer satisfaction: An empirical test in the context ofautomobile purchases. Journal of Product \& Brand Management, 16(1), 49-58. https://doi.org/10.1108/10610420710731151
Hosseinzadeh, A. (2010). Investigating consumer behavior in relation to the decision to buy green goods [Master thesis, Shahid Beheshti University].

Johri, L. M. and Sahasakmontri, K. (1998). Green marketing of cosmetics and toiletries in Thailand. Journal of Consumer Marketing, 15(3), 265-281. https://doi.org/10.1108/ 07363769810219134

Julia, T., Rahman, M. P. and Kassim, S. (2016). Shariah compliance of green banking policy in Bangladesh. Humanomics, 32(4), 390-404. https://doi.org/10.1108/H02-2016-0015

Laroche, M., Bergeron, J. and Barbaro-Forleo, G. (2001). Targeting consumers who are willing to pay more for environmentally friendly products. Journal of Consumer Marketing, 18(6), 503-520. https://doi.org/10.1108/ EUM0000000006155

Lee, K. (2008). Opportunities for green marketing: Young consumers. Marketing Intelligence \& Planning, 26(6), 573586. https://doi.org/10.1108/02634500810902839

Lee, S., Illia, A. and Lawson-Body, A. (2011). Perceived price fairness of dynamic pricing. Industrial Management \& Data Systems, 111(4), 531-550. https://doi.org/10.1108/ 02635571111133533

Leonidou, L. C., Leonidou, C. N., Palihawadana, D. and Hultman, M. (2010). Evaluating the green advertising practices of international firms: A trend analysis. International Marketing Review, 28(1), 6-33. https://doi.org/10.1108/02651331111107080

Mahenc, P. (2008). Signaling the environmental performance of polluting products to green consumers. International Journal of Industrial Organization, 26(1), 59- 68. https://doi.org/10.1016/j.ijindorg.2006.10.005

Min, H. and Galle, W. P. (2001). Green purchasing practices of us firms. International Journal of Operations \& Production Management, 21(9), 1222-1238. https://doi.org/10.1108/ EUM0000000005923

Mirzaei, K. (2010). Design and dissertation. Sociologists Publications.

Nakhaei, A. and Kheiri, B. (2012). Investigating the effect of elected factors on the intention to buy green products. Journal of Marketing Management, 7(15), 105-130.

Nelson, B., Christopher, T. and Strick, S. (2009). Wine consumers' environmental knowledge and attitudes: Influence on willingness to purchase. International Journal of Wine Research, 1(1), 59-72. https://doi.org/10.2147/ IJWR.S4649

Peattie, K. and Crane, A. (2005). Green marketing: Legend, myth, farce or prophesy? Qualitative Market Research, 8(4), 357-370. https://doi.org/10.1108/13522750510619733

Polonsky, M. J. and Rosenberger III, P. J. (2001). Reevaluating green marketing: A strategic approach. Business Horizons, 44(5), 21-30. https://doi.org/10.1016/S00076813(01)800 57-4

Prakash, A. (2002). Green marketing, public policy and managerial strategies. Business Strategy and the Environment, 11, 285-297. https://doi.org/10.1002/bse.338 
Quoquab, F. and Mohammad, J. (2016). Environmental dominant logic: Concerning for achieving the sustainability marketing. Procedia Economics and Finance, 37, 234-238. https://doi.org/10.1016/S22125671(16)301198

Quoquab, F., Mohammad, J. and Sukari, N. N. (2019). A multiple-item scale for measuring "sustainable consumption behavior” construct: Development and psychometric evaluation. Asia Pacific Journal of Marketing and Logistics, 31(4), 791-816. https://doi.org/10.1108/ APJML-02-2018-0047

Ramezanian, M. R., Esmaeilpour, R. and Tondkar, H. (2010). Impact of green marketing mix on consumer decision making process. Journal of Business Management, 2(5), 7998.

Schlegelmilch, B. B., Bohlen, G. M. and Diamantopoulos, A. (1996). The link between green purchasing decisions and measures of environmental consciousness. European Journal of Marketing, 30(5), 35-55. https://doi.org/10.1108/ 03090569610118740
Schuhwerk, M. E. and Lefkoff-Hagius, R. (1995). Green or nongreen? Does type of appeal matter when advertising a green product? Journal of Advertising, 24(2), 45-54. https://doi.org/10.1080/00913367.1995.10673475

Shah, N. (2019). Green purchasing: the issue of responsible supply chain management for improving. Available at: http://docplayer.net/8740710-Green-purchasing-theissue-of-responsible-supply-chain-management-forimproving-the-environmental-performance-presentedby-nidhi-shah.html

United Nations. (2015). The UN sustainable development goals. Available at: www.un.org/sustainabledevelopment/ summit/

Yu, Y. S., Luo, M. and Zhu, D. H. (2018). The effect of quality attributes on visiting consumers' patronage intentions of green restaurants. Sustainability, 10(4), 1187. https://doi.org/10.3390/su10041187

Zinkernagel, R., Evans, K. and Neij, L. (2018). Applying the SDGs to cities: Business as usual or a new dawn? Sustainability, 10(9), 3201. 